\title{
Loan Loss Provisions, Earnings Management and Capital Management under IFRS: The Case of EU Commercial Banks
}

\author{
Stergios Leventis* \\ International Hellenic University \\ School of Economics and Business Administration \\ $14^{\text {th }} \mathrm{klm}$ Thessaloniki-Moudania \\ 57101 Thessaloniki, Greece \\ Tel: + $302310807-541$ \\ E-mail: s.leventis@ihu.edu.gr
}

\author{
Panagiotis E. Dimitropoulos \\ University of Peloponnese \\ Department of Sport Management \\ Orthias Artemidos \& Plataion Str., P.C.23100, \\ Sparta, Greece \\ Tel: +30-2731024096 \\ E-mail: dimitrop@uop.gr \\ and \\ Asokan Anandarajan \\ New Jersey Institute of Technology \\ School of Management \\ University Heights \\ Newark, NJ 07102-1982 \\ Tel: 7325833228 \\ E-mail: Anandarajan@adm.njit.edu
}

* Corresponding author 


\title{
Loan Loss Provisions, Earnings Management and Capital Management under IFRS: The Case of EU Commercial Banks
}

\begin{abstract}
Prior research has shown that loan loss provisions are primarily used as a tool for earnings management and capital management by listed banks. Effective 2005 all listed companies in the European Union (EU) are required to comply with International Financial Reporting Standards (IFRS). Adherence to IFRS, it is claimed, should enhance transparency of reporting practices relative to local General Accepted Accounting Principles (GAAP). The overall objective of this paper is to examine the impact of the implementation of IFRS on the use of loan loss provisions (LLPs) to manage earnings and capital. We use a sample of 91 EU listed commercial banks covering a period of ten years (before and after implementation of IFRS). Since early adopters may have different incentives and motivations relative to those who adopt mandatorily, we dichotomize our sample into early and late adopters. Overall, we find that earnings management (using loan loss provisions) for both early and late adopters while significant over the estimation window is significantly reduced after implementation of IFRS. We also find that, for risky banks, earnings management behavior is more pronounced when compared to the less risky banks, but is significantly reduced in the post IFRS period. Capital management behavior by bank managers is not significant in both pre and post IFRS regimes. Overall, we conclude that the implementation of IFRS in the EU appears to have improved earnings quality by mitigating the tendency of bank managers of listed commercial banks to engage in earnings management using loan loss provisions.
\end{abstract}

Key words: Earnings management, capital management, loan loss provisions, IFRS, European Union.

JEL codes: C23, G14, M41 


\section{Loan Loss Provisions, Earnings Management and Capital Management under IFRS: The Case of EU Commercial Banks}

\section{Introduction}

Prior research shows that loan loss provisions (LLPs) are used as a tool to manage earnings by listed banks (Ahmed et al. 1999; Anandarajan et al. 2003, 2007; among others). Effective 2005 all listed companies in the European Union (EU) are required to comply with International Financial Reporting Standards (IFRS). It has been stated that IFRS will improve transparency of reported practices by institutions (Barth et al. 2008). The questions we address are: first, whether the association of LLPs with earnings management is significantly changed under IFRS for listed banks in the European Union, and secondly if IFRS changes the association of LLPs and capital management.

The primary motivation for this study is to extend our understanding on the influence of IFRS on the quality of reported earnings by focusing our attention on the use of LLPs for earnings and capital management. Overall, IFRS are principle-based standards that are market oriented and require extensive disclosure relative to prior standards i.e., local generally accepted accounting principles (GAAP). The International Accounting Standards Board (IASB) removed allowable accounting alternatives (that existed in most countries under their respective GAAPs) and requires accounting measurements that better reflect a firm’s economic position and performance. In essence, IFRS are precise, admit a very limited number of options, and prohibit hidden reserves. Based on this, in theory, the adoption of IFRS should significantly reduce the ability to engage in earnings management behavior. IFRS limits the opportunity of management to engage in 
opportunistic behavior by limiting the accounting options available to them (Barth et al. 2008).

However, financial institutions have a contrary view regarding limiting the options available to them in determining LLPs. For example, the ING annual report of 2007 makes the comment (also made by many other financial institutions such as Citibank) that the application of the IFRS will reduce the amount of the unallocated provision for loan losses that banks provide in prior years to adequately capture various subjective and judgmental aspects of credit risk assessment which are not considered on an individual basis. The inference is that stricter rules will reduce the subjectivity previously (pre IFRS) allowed to managers which according to ING and others is essential to "capture subjective aspects of credit risk”. Hence, financial institutions appear to be not favorably disposed to stricter rules noting that under IFRS, loan loss provisions will be determined based on a narrow interpretation that will act as a detriment to banks in determining LLPs that adequately capture credit risk. Part of the motivation of this paper is to show that, despite the negative attitudes of financial institutions, the IFRS has been beneficial to users of financial reports due to enhanced quality generated by lower levels of earnings management in the post IFRS period.

Barth et al. (2008) echo the sentiments expressed by financial institutions such as ING. They (ibid.) note that limiting managerial discretion relating to accounting alternatives could eliminate a firm’s ability to report accounting measurements that are more reflective of the firm's economic position and performance. They also note that if 
enforcement of these standards is lax, companies could still engage in earnings

management. On the one side some researchers argue that by limiting managerial discretion and removing the element of subjectivity, IFRS may improve the reliability of financial reporting (Ashbaugh and Pincus 2001; Barth et al. 2008; Ewert and Wagenhofer 2005). The contrary view is that allowing less latitude by admitting a very limited number of options may actually reduce the quality of reported earnings (Ball et al. 2003; Breeden 1994; Burgstahler et al. 2006; Cairns 1999; Street and Gray 2002; among others). Part of the motivation of this study is to shed further light on the competing views with regard to the efficacy of IFRS in reducing earnings management and improving earnings quality (with particular emphasis on the use of LLPs by listed banks).

Our study adds to a growing body of literature in several ways: 1) prior studies (subject to Barth et al., 2008) focus on single country level which limits the generalization of the results. We use a unique dataset of 91 listed banking firms originating from 18 European countries; 2) this is the first study to test if and how earnings (and capital) management via the use of loan loss provisions (LLPs) are influenced in any way by the implementation of IFRS. We thus provide additional evidence on the ongoing debate about international accounting standards and whether such standards contribute to enhancing the quality of reported earnings; 3) we consider the impact of insolvency risk as a distinct factor on the use of LLPs for capital and earnings management; 4) finally, we note that the issue of "loan provisioning" is in the agenda of many regulatory bodies responding to the current financial crisis (EFRAG 2009). This is an area that is considered important because some researchers have documented that, in a particular 
setting (for example, Japan) banks report positive capital adequacy ratios by not fully recognizing loan losses (Hasan and Wall 2004). Currently the Financial Stability Board (FSB 2009) in its report of the FSB to G20 leaders noted that Basel Committee on banking supervision is working urgently to build stronger "buffers" into the financial system covering, among others, loan loss provisioning. New rules in this area will be finalized within 2010. The objective of the new rules is to improve the quality of reported capital. It is noted that the predominant form of Tier 1 capital in the numerator of the capital adequacy will be common stock and retained earnings. However, adjustments in LLPs will affect retained earnings. Hence, research projects dealing with LLPs and factors influencing provisioning will be relevant to regulators in their attempt to achieve a "step up" in the quality of reported capital. This research, by demonstrating the influence of IFRS on loan loss provisioning, may provide information useful to regulators.

Our sample comprises 91 listed commercial banks originating from 18 European countries covering a ten year period. We compare earnings management behavior prior to and after adopting IFRS standards. Most prior research suggests that the primary tool for managing earnings by commercial banks is loan loss provisions (Anandarajan et al. 2003; Ahmed et al. 1999; Beatty et al. 1995; Collins et al. 1995; Greenawalt and Sinkey 1988; Kim and Kross 1998; Liu et al. 1997; Moyer 1990; among others.) In particular, IFRS in International Accounting Standard (IAS) No. 39 provide guidance on how loan loss provisions should be established and limits the ability of managers to exercise flexibility in determining the provision (IASB, 2003). If the ability to use LLPs to manage earnings are limited then we should find evidence of lower earnings management 
post IFRS. Since earnings management and capital adequacy ratios are intrinsically linked according to these studies, we also examine the influence of IFRS on capital management. After controlling for the macro-economic conditions in each country of our sample and for bank size we find that the adoption of IFRS has significantly changed earnings management behavior (i.e., earnings management is relatively lower in the post IFRS period). Risky banks in our sample engaged in relatively greater earnings management when compared to the less risky banks but significantly reduced opportunistic behavior in the post IFRS period. We also find that LLPs are not used to manage capital to avoid capital adequacy ratio constraints.

In the next section we discuss the regulatory environment in the European Union with particular reference to loan loss provisions. Section 3 discusses the relevant literature and develops our hypothesis. Section 4 deals with our research methods. Section 5 presents the results and the final section provides our conclusions.

\section{Regulatory Environment of European Banking}

Bank accounting in Europe initially varied by country (World Bank 2003). The definitions of what should comprise regulatory capital also varied by country with each country's regulatory body setting their own respective levels and standards. In order to overcome this and to level the competitive conditions for banks across different countries, the Basel committee issued two accords (Busch 2009). Basel I introduced minimum capital requirements (Tier 1 and Tier II). The requirements of this accord subsequently extended to more than a hundred countries worldwide. Basel I inadvertently created 
loopholes which, according to Anandarajan et al. (2003, 2007) and Perez et al. (2008) enabled banks to engage in more aggressive earnings management. Prior to Basel I if a bank attempted to reduce loan loss reserves to increase earnings, it adversely affected the capital adequacy ratio since loan loss reserves were part of the numerator of the capital adequacy ratio (Busch 2009). However, Basel I limited loan loss reserves in the numerator of the capital adequacy to $1.25 \%$ of risk weighted assets. Since this was not a significant component of the numerator banks could reduce loan loss reserves without significantly deteriorating the capital adequacy ratio. Researchers concluded that this encouraged managers to engage in more earnings management. Basel II initially published in June 2004 and adopted by the EU in 2005 was implemented in January 2008 (Tarullo 2008). The scope of Basel II was to create an international standard to guard against operational and financial risk (BCBS 2005a, 2005b, 2005c). While the accord did not change the structure of the capital adequacy ratios with regard to the amount of loan loss reserves in the numerator, it required banks to separate loans into categories according to the probability of default. The purpose was to reduce discretionary judgment by bank managers (BIS 2005).

EU banks were required to adopt IFRS in January 2005. Loan loss provisions were regulated by IAS No. 39. This made certain changes relative to loan loss reserves (see IASC 2003; Grier 2005; PWC 2009), namely:

- Certain assets were required to be classified as investments under IFRS without loan loss provisions. 
- No general provisions allowed. (Earlier bank managers could make a "general" provision to loan loss reserve without identifying potential default customers).

- LLPs are to be determined based on an incurred loss model supported by objective evidence of impairment (either due to a single loss event or a group of events). This was similar to the categorization required by Basel II accord.

- LLPs cannot reflect losses based on expected future events (which was allowed previously).

These changes were expected to replace subjective judgments with objective judgments and reduce the ability of managers to manipulate loan loss reserves (and thus mitigate the possibility of earnings management). However, no study to date has tested whether earnings management is indeed mitigated.

We now discuss relevant prior literature and develop our hypotheses.

\section{Literature Review and Hypotheses Development}

While two conflicting views exist on the influence of IFRS as noted in section 1, research on the influence of IFRS on earnings management has provided mixed results. Van Tendeloo and Vanstraelen (2005) for example, find that earnings management behavior is not significantly different between companies in Germany that adopted IFRS and those that did not adopt and relied on German GAAP. However, these findings are not corroborated by Barth et al. (2008) who, using a sample of 21 countries conclude that in the post adoption period, firms applying IFRS display significantly less earnings 
management relative to the pre-adoption period. These are the only two published studies examining the influence of IFRS on earnings management. These two studies use data comprising different non-financial industries (Barth et al. 2008 in particular straddling 21 countries). While they use heterogenous data in that they include a variety of industries in their sample, we contribute to the extant literature by using homogenous data. Our sample comprises financial institutions in the form of commercial listed banks only. We expect that the results will be more meaningful if we focus on one specific industry. We now develop our hypotheses.

\subsection{LLPs and Earnings Management}

The banking industry has been characterized as more prone to earnings manipulation when compared to other industries (Greenawalt and Sinkey 1988). The seminal paper by Scheiner (1981) examines a sample of US commercial banks and concluded that LLPs are an important tool used by bank managers for managing earnings. Ma (1988) and Greenawalt and Sinkey (1988) provide evidence that bank managers tend to raise LLPs in periods of high operating income in order to lower volatility of reported earnings. These findings are supported by many studies focusing on US banks (Ahmed et al. 1999; Beaver and Engel 1996; Collins et al. 1995; Healy and Wahlen 1999; Liu et al. 1997; Liu and Ryan 1995; Scholes et al. 1990; among others). All these studies concluded that, in the US especially, LLPs are used by banks as a mechanism for aggressive earnings management, mainly for stock market purposes. Studies using non-US banks also arrive at similar conclusions (Anandarajan et al. 2003, 2007; Perez et al. 2008).

Thus we hypothesize that: 
H1a: Loan loss provisions will be positively associated with earnings (before tax and loan loss provisions).

A goal of the IASB is to develop an internationally acceptable set of high quality financial reporting standards (IASB 2008). To achieve this goal, the IASB, as previously mentioned, adopted principles-based standards, removed alternative accounting treatments and encouraged more rigorous enforcement (IASB 2008). Empirical evidence suggests that limiting opportunistic discretion increases quality of reported earnings (Ashbaugh and Pincus 2001; Ewert and Wagenhofer 2005). Armstrong et al. (2010) find a positive market reaction for EU companies, particularly banks, after adoption of IFRS. Stock market investors apparently view the adoption of IFRS as improving earnings quality in the presence of reduced managerial discretion and reacted accordingly. Barth et al. (2008) using a sample of 21 countries reports evidence that companies adopting IFRS reduced earnings management. ${ }^{1}$ Thus, we hypothesize:

H1b. The relation between loan loss provisions and earnings (before tax and loan loss provision) will be negative in the post IFRS regime relative to the pre IFRS regime.

1 We do not follow Barth et al. (2008) model since we focus only on financial institutions. Nonfinancial institutions have different characteristics to non-financial institutions i.e. necessity to meet capital adequacy ratios. Hence, the design of Barth et al, might not be directly suited for nonfinancial institutions. 
Banks facing increased levels of solvency risk could have an incentive to manage earnings in order to avoid costs related to regulatory intervention. Yasuda et al. (2004) provide evidence that troubled banks engage in excessive window dressing in profits by, among other strategies, adjusting for provisions for bad loans. Bhat (1996) finds a significant association between poor financial health and banks engaging in excessive earnings management. Therefore, banks facing a higher probability of insolvency may have greater incentives for using LLPs to manipulate reported accounting numbers. However, IFRS, in theory, should reduce the ability of bank managers to engage in earnings management. We therefore hypothesize:

H1c. The relation between LLPs and earnings (before tax and loan loss
provision) will be more negative for riskier banks in the post IFRS regime

\subsection{LLPs and Capital Management}

In this paper we also examine whether the IFRS have influenced capital management behavior for the banks in our sample. The use of LLPs to manipulate the capital adequacy ratio has been documented by prior research (Beatty et al. 1995; Collins et al. 1995; Moyer 1990; Scholes et al. 1990). The incentive for manipulating the capital adequacy ratio arises because violation of this ratio will incur regulatory costs (Anandarajan et al., 2003). The results of the research are not conclusive. Some studies report evidence of a negative association between LLPs and capital ratios verifying the existence of capital management behavior (Beatty et al. 1995; Scholes et al. 1990). However, Collins et al. (1995) found no evidence of capital management behavior. These studies used data prior 
to the Basel I accord. Kim and Kross (1998) and Ahmed et al. (1999) examined whether LLPs were used to manage capital adequacy ratios after the implementation of the Basel I accord and found evidence of the existence of capital management using LLPs. Wall and Koch (2000) in a later study also corroborated the findings of Ahmed et al. (1999) and Kim and Kross (1998). These studies used US banks. In studies using banks from other industrialized countries, Anandarajan et al. (2003, 2007) and Perez et al. (2008) found no evidence for the Australian and Spanish banking sectors. Hence, overall, the results appear to be conclusive that banks, especially after the implementation of Basel Accord I do not engage in capital management behavior using LLPs due to the restrictions imposed by the Accord. However, motivations for capital management still exist and might be a strong incentive for banks facing higher costs for violating capital requirements (Anandarajan et al., 2003). Consequently we hypothesize that banks with relatively higher costs of violating minimum capital requirements will engage in more capital management. Our hypothesis is stated as follows:

H2a: $\quad$ The higher the cost of capital adequacy violation, the greater the propensity for banks to manage capital using LLPs.

Before the adoption of IFRSs, European companies had only very general EU guidance on loan loss provisioning (Laurin and Majnoni 2003). Therefore, banks relied on country specific accounting regulations and supervisory guidelines in assessing provisional levels. National tax deductibility of loan losses provided a strong incentive for EU banks to either set aside adequate loan loss provisions or to set provisions relative to tax acceptable levels in order to benefit from tax deductions but retain capital adequacy. The 
Basel Committee requires banks to use accounting principles reflecting prudent and conservative valuation in their loan loss provisioning decisions (Hasan and Wall 2004). European banks have applied the Fourth Directive under which banks operate under accrual accounting regardless of the timing of cash flows. However, accruals might have been applied prudently based on a multiple set of factors across different EU banks (ibid). While banks operating under IFRS need to determine specific and general allowances of loan losses, general allowances are very restricted (Epstein and Jermakowich 2007).

The adoption of IFRS by EU member countries influenced measurement and disclosure practices on several aspects by introducing a more strict definition of equity on several grounds: 1) EU banks are obliged to classify similar financial instruments into common categories and disclose information relevant to their significance, nature and risks (Epstein and Jermakowich 2007). Asset values and risk are linked with economic capital and entities are obliged to present data about exposure to several banking risks; 2) IFRS requires specific preferred shares and hybrid instruments previously classified as equity (and included in Tier 1 capital) to be classified as liabilities. This significantly affects the regulatory capital (APRA 2005). Taken together, we expect that specific regulations and restricted equity will reduce discretionary management ${ }^{2}$. Consequently, the second part of our second hypothesis states:

2 In the presence of strict and specific rules (less discretion) in the use of LLPs (post IFRS period) the amount of loan loss provision may be relatively higher compared to the pre IFRS period. Our data (see Table 2) support this. LLPs are no longer part of the numerator of the capital adequacy ratio. However, retained earnings are part of the numerator. When loan loss provisions are relatively higher, the bad debt expenses are relatively higher which reduces retained earnings. Retained earnings are part of the numerator of the capital adequacy ratio. So the numerator of the capital adequacy ratio will be relatively lower causing the capital adequacy ratio to be relatively lower (relative to pre IFRS). Hence, when capital adequacy is low there is an incentive to decrease LLPs to improve the capital adequacy ratio. 
H2b. Banks will have a lower propensity in the post IFRS regime to manipulate loan loss provisions to manage capital.

Finally, we consider the impact of solvency risk as an important factor which drives managerial decisions on capital management. Solvency risk indicates the probability of bankruptcy. From a finance perspective, financial institutions retain capital in order to resolve agency conflicts between shareholders, depositors, creditors and guarantors (World Bank 2003). Under this framework, equity provides assurances appropriate to risk levels. Bank capital provides confidence to depositors and creditors which in turn determine the security of the bank and the stability of the financial system in total (Anderson and Fraser 2000). Likewise, the bank's net worth and the stability of earnings (assuming uniform disclosure of quality information) are important for market confidence. Since it is common to consider bank capital as a cushion to absorb unexpected losses arising from credit risk, interest rate risk and liquidity risk, banks’ capital is a critical element for generating confidence about their ability to handle uncertainty. This fact suggests an inverse relationship between the level of bank capital and risk exposure (Boyd et. al. 1993; Shrieves and Dahl 2003; Yasuda et. al. 2004), although very high levels of capital might suggest low asset quality (Iannotta 2006). Consequently, we expect bank managers who face low levels of solvency risk to have fewer incentives for masking the bank’s capital. Thus, we hypothesize:

H2c. More risky banks will have a greater incentive to manipulate capital via LLPs than less risky banks. 


\section{Data \& Methodology}

\subsection{Data \& Sample Selection}

The dataset used in our study is limited to EU listed commercial banks for a tenyear period (1999-2008). During the specific time frame the commercial banks were subject to two major regulatory changes, namely, the requirement to implement IFRS on January 2005 and the implementation of the Basel II Accord ${ }^{3}$. Data were extracted from Thomson 1 Banker database and carefully reviewed for any data inconsistencies and availability. Commercial banks with incomplete data, central banks, government development banks, cooperative banks and export-import banks were excluded from the sample. This procedure produced a final sample of annual end-of-year information for 91 listed commercial banks originating from 18 EU countries, including Switzerland ${ }^{4}$, with a total number of 910 firm-year observations. Table 1 presents the data selection procedure. We did not proceed in any curtailing of the data in the upper and lower bounds of the distributions because the data are quite dispersed within countries and we also did not want to lose any further observations which could deteriorate the validity of our inferences.

[Insert Table 1 about Here]

3 The requirements of Basel II accord do not impinge on the requirements of IFRS and hence there is no confounding effect.

4 Swiss banks are not officially part of the EU as yet. However, all Swiss banks follow all European legislation and the Basel accord. They also implemented IFRS with other European countries. Since they comply with all relevant legislation applicable to this study, banks from Switzerland have been included in our sample. 


\subsection{Testing for Capital and Earnings Management}

The model that we use for testing capital and earnings management is a modified version of the model used by Ahmed et al. (1999). The empirical foundation of this study is based on relating bank's loan loss provisions to the underlying financial information disclosed in the financial statements and specifically earnings and Tier 1 capital. Particularly, the model that we use for testing the capital and earnings management hypotheses is a modified and extended version of the cross-sectional model used by Ahmed et al. (1999) and Anandarajan et al. (2003, 2007). The difference is that they examined how Basel I accord influenced earnings and capital management behavior. We examine how implementation of IFRS influences earnings and capital management behavior via LLPs. Since this model has been tried and tested it is appropriate for our study.

The specific model presents some changes relative to the model proposed by Ahmed et al. (1999) since our objective is to examine the impact of IFRS adoption and insolvency risk on the discretion of bank managers to mask banks' capital and earnings via LLPs. For this reason we introduced two dichotomous variables, IFRS and Dz, which capture the impact of different accounting regimes and the level of insolvency risk respectively on the discretionary use of LLPs for capital and earnings management. Even though Anandarajan et al. $(2003,2007)$ take into consideration the impact of risk, their research framework is limited because they use only one explanatory variable (change in annual 
loan losses). On the contrary in our framework we estimated the Z-index, developed by Boyd et al. (1993), which defines bankruptcy as the situation where losses exceed equity in market values. Therefore, this metric provides a clearer picture of the actual number of standard deviations below the mean by which profits must fall in order to eliminate equity. The description of the model and the analysis of the variables are presented as follows:

$$
\begin{aligned}
L L P R_{i t}= & a_{0}+a_{1} M C A P_{i t}+a_{2} E B T_{i t}+a_{3} I_{F R S_{i t}}+a_{4} I_{F R S_{i t}} * M C A P_{i t}+a_{5} I F R S_{i t}^{*} E B T_{i t} \\
& +a_{6} D z_{i t}+a_{7} D z_{i t} * M C A P_{i t}+a_{8} D z_{i t} * E B T_{i t}+a_{9} I F R S_{i t} * D z_{i t} * M C A P_{i t} \\
& +a_{10} I F R S_{i t} * D z_{i t} * E B T_{i t}+a_{11} L n T A_{i t}+a_{12} C F E E R_{i t}+a_{13} \Delta G D P_{i t}+a_{14}
\end{aligned}
$$

DCROSS $_{i t}$

$$
+b \text { Country dummies }+ \text { cYear dummies }+e_{i t}
$$

Where:

$$
\begin{array}{lll}
\text { LLPR } & \text { Ratio of loan loss provisions to total loans } \\
\text { MCAP } & \text { Ratio of actual regulatory capital (Tier } 1 \text { capital) before loan } \\
& \text { loss reserves to the minimum required regulatory capital } \\
\text { EBT } & \text { Ratio of earnings before taxes and LLPs to total assets } \\
\text { IFRS } & =\text { Dummy variable. (1) if banks report under IFRSs, (0) otherwise } \\
\text { IFRS*MCAP } & = & \text { Interaction of MCAP with type of accounting regime (IFRS) } \\
\text { IFRS*EBT } & = & \text { Interaction of EBT with type of accounting regime (IFRS) } \\
\text { Dz } & = & \text { Dummy variable (1) for observations lying below the sample } \\
& & \text { median of the Z-score (developed by Boyd et al. 1993), (0) }
\end{array}
$$


otherwise

$\begin{array}{ll}\text { Dz*MCAP } & =\text { Interaction of Dz with MCAP } \\ \text { Dz*EBT } & =\text { Interaction of Dz with EBT } \\ \text { IFRS*Dz*MCAP } & =\text { Interaction among IFRS, the level of risk Dz, and MCAP } \\ \text { IFRS*Dz*EBT } & =\text { Interaction among IFRS, the level of risk Dz, and EBT } \\ \text { LnTA } & =\text { Natural logarithm of total assets } \\ \text { CFEER } & =\text { Ratio of commission and fee income to total assets } \\ \Delta \text { GDP } & =\text { Dummy variable. (1) if banks are cross-listed, (0) otherwise } \\ \text { DCROSS } & =\text { Error term }\end{array}$

The Z score is a metric for bank insolvency risk developed by Boyd et al. (1993). The Z score is a statistic indicating the solvency for each bank $\mathrm{j}$ in every year $\mathrm{t}$ and is calculated as follows:

$$
Z=\frac{\sum_{j=1}^{12}\left(\pi_{j} / A_{j}\right)+\sum_{j=1}^{12}\left(E_{j} / A_{j}\right)}{S_{r}}
$$

where $\pi_{\mathrm{j}}$ is the estimated market value of total profit (the subscript $\mathrm{j}$ denotes the month) that can be calculated as follows:

$$
\pi_{j}=c_{j} p_{j}-c_{j-1} p_{j-1}
$$

where $c_{j}$ is the number of outstanding shares adjusted for stock splits, and $p_{j}$ is the share price of the last business day of month $\mathrm{j}^{5}$. $\mathrm{E}_{\mathrm{j}}$ is the market value of total equity (e.g. share prices multiplied by number of shares outstanding); $A_{j}$ is the market value of total assets:

$5 \quad$ We have modified the estimation of Boyd et al. (1993) on the market value of profits following Yasuda et al. (2004) by excluding dividends from the stock price since Penman (2001, p. 106) and 


$$
A_{j}=E_{j}+L
$$

$\mathrm{L}$ is the book value of total debt at the end of each fiscal year and $\mathrm{S}_{\mathrm{r}}$ is the estimated standard deviation (SD) of $\pi_{\mathrm{j}} / \mathrm{A}_{\mathrm{j}}$. The market value of total assets and total equity are averaged monthly. The Z score is negatively associated with insolvency risk as a low Zscore indicates a high probability of bankruptcy. $\mathrm{Z}$ is the number of SDs below the mean by which profits must fall in order to eliminate equity. Boyd et al. (1993) defines the downside risk as being negative values of the $\mathrm{Z}$ score (see Yasuda et al. 2004). In other words, the higher the value of the Z-score the lower the insolvency risk.

We have also included in the model country dummies in order to encapsulate any unobservable country specific effects. We have also included year dummies to capture time specific effects and also to deal with the problem of heteroscedasticity in the error term. We control for the IFRS and solvency risk impacts separately and concurrently by introducing relevant factors gradually in the empirical model in order to examine the effect of each factor on a manager's decision to mask earnings and capital via LLPs.

In model (1) we take into consideration the impact of IFRS adoption by European countries on the management of capital and earnings. We have introduced a second dichotomous variable $\mathrm{Dz}$ which captures the effect of insolvency risk. We expect a negative association with LLPs. Similar to Anandarajan et al. (2007) we use the ratio of earnings before taxes and loan loss provisions to total assets (EBT) and the interaction

Kothari (2001, p. 174) argue that dividends have no effect on the value of the firm because firm value depends on the forecasted profitability of current and forecasted future investments. Also empirical evidence by Chang and Chen (1991), Barro (1990), Blanchard et al. (1993) and Penman and Sougiannis (1997) verify the aforementioned assertions and suggest that it is appropriate to measure stock prices exclusive of dividends. 
term IFRS*EBT to test the use of LLPs for earnings management during the pre and postIFRS periods. We expect IFRS to contribute to less earnings management practices by banks. Consequently, we expect a positive coefficient for EBT if bank managers' decisions on loan loss provisions are motivated by earnings management. The coefficient of the interaction term IFRS*EBT (which captures the impact of IFRS on earnings management via LLPs) is expected to be smaller in size relative to the coefficient of the pre-IFRS period.

We have also included the interaction term Dz*EBT to examine the earnings management in relation to insolvency. Overall, if high risk banks use LLPs to manage earnings relative to low risk banks, we expect a positive coefficient. We also test the interaction between IFRS, insolvency and earnings (IFRS*Dz*EBT). If high risk banks use LLPs more aggressively to manage earnings in the post-IFRS period the coefficient will be positive and statistically significant.

Similar to Anandarajan et al. (2003, 2007), Ahmed et al. (1999) and Beatty et al. (1995) we use the ratio of actual regulatory capital before loan loss reserves to the minimum required regulatory capital (MCAP) to examine the use of LLPs for capital management. We expect a negative sign on the coefficient of MCAP. The variable IFRS*MCAP measures the difference in the use of LLPs for capital management in the post-IFRS period. We expect the relationship between LLPs and capital management to decline after the issuance of IFRS. 
Additionally, the interaction variable Dz*MCAP is included to examine whether solvency is related to incentives for capital management. A negative coefficient is expected. The variable IFRS*Dz*MCAP indicates the interaction of high risk banks with capital adequacy ratio in the post-IFRS regime. If the incentive to use LLPs to manage capital is higher for high risk banks we expect a negative coefficient.

Our model includes several control variables. Similar to Perez et al. (2008) we include the natural logarithm of total assets as a control variable for bank size. Although the relation between LLP and size is non monotonic we expect that higher credit portfolio diversification for big banks will result in a negative sign. Similar to Anandarajan et al. (2007) we include the ratio of commission and fee income to total assets (CFEER). A higher CFEER ratio indicates a bank's greater interest in non-depository activities. Under these circumstances banks may allocate additional LLPs to provide a sense of confidence and safety to the market. $\triangle \mathrm{GDP}$ is the annual growth rate of every country's gross domestic product. This variable captures the effect of macroeconomic conditions (business cycle) on loan loss provisions (Perez et al. 2008). Thus, we control for LLP cyclical pattern. We expect a negative coefficient because in the presence of a downturn we expect banks will reduce loan loss provisions to inflate earnings. Finally, following Lang et al. (2006) we have included DCROSS to indicate bank coss-listings. We expect a positive association because greater cross listing may provide an incentive to manipulate earnings to inflate stock price in the different exchanges.

\section{Empirical Results}




\subsection{Descriptive Statistics \& Correlations}

Descriptive statistics for the full sample (pre-IFRS and post-IFRS) are presented in Table 2 Panel A. The mean (median) value of LLP in the pre-IFRS period is 0.0057 (0.0044) while the mean (median) value in the post-IFRS period increases to 0.0063 (0.0052). The mean (median) value of Tier 1 capital over the minimum required capital (MCAP) shows a significant decrease from $1.789(0.706)$ in the pre-IFRS period to 1.087 (0.739) in the post-IFRS period ${ }^{6}$. Descriptive statistics for voluntary adopters are similar and reported in Table 2 Panel B. Untabulated descriptive statistics suggest a wide variation between different countries in terms of LLPs and MCAP pre- and post-IFRS. While banks' LLPs have increased significantly in some countries (e.g. Hungary, Greece, Spain, France and UK), banks in other countries seem to have deteriorated levels of LLPs (Denmark, Germany, Norway, Poland and Portugal) while in a few countries banks’ LLP levels have not changed significantly (e.g. Sweden, Italy, Belgium, Austria). There is also a wide variation for MCAP between different EU countries. Some countries evidenced a material decrease (e.g. Greece, Portugal, Spain, Sweden, Switzerland, Denmark); some countries evidenced an increase (Germany, Italy, Portugal, UK, Finland, Poland); and some did not show any significant difference (e.g. Austria, Belgium, France, Hungary, Norway, Luxemburg).

[Insert Table 2 about Here]

6 Our untabulated findings indicate a material increase in both provisions and liabilities in the post IFRS era. While some increase was anticipated due to increase of liabilities by following new accounting methods (IAS 39 reporting liabilities at fair values gross), the increase in LLPs was proportionately higher. 
Table 3 provides the Pearson correlation coefficients of the sample variables. LLPs are positively and significantly correlated to EBT (0.194) and are significantly negatively to LnTA (-0.066). This indicates that larger banks have relatively lower LLP. Presumably they consider that their loans are not risky, or alternatively, may be lowering LLPs to inflate earnings. LLPS are not significantly correlated with MCAP and $\triangle$ GDP. LLPs are positively and significantly correlated with CFEER (0.094). As banks increase their fees and commissions due to increased business, the increase in customers may increase perceived probability of default. Banks may be reacting to this by increasing LLPs. These results are consistent with prior studies. Multi-collinearity has also been tested through Variance Inflation Factor (VIF) and eigenvalues; both suggest that multicollinearity problems are not serious.

[Insert Table 3 about Here]

\subsection{Findings on Capital Management and Earnings Management}

\subsubsection{Earnings management}

Estimates of the four different specifications in our model are reported in Tables 4 and 5 (hereafter referred to as model specification $1 \mathrm{a}, 1 \mathrm{~b}, 1 \mathrm{c}$ and $1 \mathrm{~d}$ in each table respectively). Cairns (1999) and Street and Gray (2002) suggest that early adopters might follow a differential approach to accounting quality when compared to mandatory adopters. Since early adopters could have different incentives and motivations from mandatory adopters, we broke down our sample into those adopting early (Table 4) and those 
adopting only when they were mandatorily required to (Table 5). All model specifications include EBT enabling us to test H1a, namely that LLPs are positively associated with earnings. Similarly, all model specifications include the capital ratio (MCAP) enabling us to test the association of variations in capital ratios with LLPs (H2a). Model specifications 1a, 1c and 1d includes the interaction of the dichotomous variable IFRS with EBT testing if there were any changes in the association of LLPs and earnings in the post IFRS regime (H1b). The model specifications 1a, 1c and 1d also include the interaction of the dichotomous variable IFRS with MCAP testing changes in the association of LLPs with capital management in the post IFRS regime (H2b). Model specifications 1b, 1c and 1d includes the interaction DzEBT testing whether risky banks will have greater incentive to manipulate earnings via LLPs relative to less risky banks (H1c). Model specifications, 1b, 1c and 1d also include the interaction variable Dz*MCAP testing if banks with relatively higher costs of violating minimum capital requirements (i.e., troubled banks) engage in greater capital management using LLPs (hypothesis H2c). The last specification includes the interaction variable IFRS*Dz*EBT testing if earnings management by riskier banks are more pronounced in the post IFRS regime. All model specifications have been estimated including country and year dummies.

The coefficient of EBT is positive and significant at the five per cent level in all model specifications (in both Tables 4 and 5) which supports hypothesis H1a. Our conclusion is that LLPs are used for earnings management purposes over our entire period of analysis. This finding corroborates the findings of other researchers (refer Ahmed et al. 1999; 
Anandarajan et al. 2003, 2007 and Perez et al. 2008). The coefficient of the interaction IFRS*EBT is statistically significant at the five percent level in our model specification 1d in both Tables 4 and 5). This finding suggests a significant decline in earnings management behavior using LLPs in the post IFRS regime relative to the pre IFRS regime. This finding supports our hypothesis H1b which predicted significantly lower propensity to engage in earnings management in the post IFRS regime. (Even though the IFRS*EBT variable was not significant in models 1a and 1c, we make our conclusion from the results of model 1d because this model is the "full" model incorporating all control variables and interactions).

While we have interpreted the positive coefficient of the EBT variable and the interactive variable as indicative of LLPs being used for earnings management purposes and that a significant decline in earnings management behavior took place in the post IFRS regime, an alternative explanation based on prudent risk management is possible ${ }^{7}$. When the economic cycle is positive, bank loans grow and bank profits tend to be relatively higher. In this scenario, more prudent banks may increase their loan loss provisions because these are the times when expected losses are generated and growing. However, the introduction of strict accounting rules based on the concept of "incurred loss" does not allow management discretion with respect to "expected losses" as the basis for loan loss provisioning. Following the prudent risk management rationale, one could provide an alternative explanation as to why riskier and smaller banks with less diversified loan portfolios have higher provisions. This is an important issue for further research considering that the main topics underlying the ongoing debate concerning the reform of

\footnotetext{
${ }^{7}$ We thank an anonymous reviewer for this suggestion.
} 
bank prudential regulation is related to loan loss provisions. Different regulatory bodies endorse the idea of a more dynamic provisioning framework (Financial Stability Board, Basel Committee) where banks are allowed to increase provisions based on expected losses.

\subsubsection{Capital management}

The results for the MCAP variable (in model specifications, 1a, 1b, 1c and 1d in Tables 4 and 5) show that the variable is negative (in all models except 1a in Table 4) but not statistically significant. This indicates insufficient evidence to support our hypothesis H2a that LLPs are used to manage capital adequacy ratios. When IFRS*MCAP is included (refer model specifications 1a, 1c, and $1 \mathrm{~d}$ in Tables 4 and 5) the coefficient is negative but not significant. This indicates insufficient evidence to support our hypothesis H2b that LLPs will be used more aggressively to manage capital in the post IFRS regime. Overall, we conclude that LLPs are not used as a tool for capital management.

In all model specifications in both Tables 4 and 5 , the dummy variable $\mathrm{Dz}$ is negative and statistically significant (at the one percent level) indicating that high risk banks maintain higher levels of loan loss provisions relative to low risk banks. The interaction term Dz*MCAP is not statistically significant (refer model specifications $1 \mathrm{~b}, 1 \mathrm{c}$ and $1 \mathrm{~d}$ ) suggesting that insolvency risk is not significant for variations in capital management. This indicates insufficient evidence to support our hypothesis H2c predicting that more risky banks will use LLPs more aggressively to manage capital ratios relative to less risky 
banks. However, the interaction term DZ*EBT is positive and statistically significant (at the one percent level) in the full model (model 1d) in both Tables 4 and 5 suggesting that banks with higher probability of insolvency have greater propensity to use LLPs for manipulating accounting income numbers across our entire sample over the entire time period. This finding corroborates our hypothesis H1c.

The coefficient of the IFRS dummy was negative but not significant in all model specifications in which it was included (1a, 1c and 1d). In the full model the coefficient of the three-way interaction variables IFRS*Dz*EBT is negative and significant at the one percent and five percent levels in Tables 4 and 5 respectively. The negative significant coefficient of IFRS*Dz*EBT (refer to model specification 1d in Tables 4 and 5) indicates that in the post IFRS regime, riskier banks engage in lower earnings management using LLPs. This finding further supports hypothesis H1c. The insignificance of the IFRS*Dz*MCAP three way interaction variable (refer to model specification 1d) indicates that there is insufficient evidence to indicate that high risk banks use LLPs to avoid capital adequacy violation in the post-IFRS era. With respect to the control variables, bank size and the level of economic growth seem to negatively affect the level of LLPs (in all model specifications). Our evidence indicates that relatively smaller banks maintain higher levels of LLPs. This may be attributed to less efficient strategies to credit risk diversification. The negative coefficient of the GDP growth variable is indicative of the cyclical pattern of LLPs (i.e. banks in periods of recession tend to maintain increased provisions for protection against unexpected losses). Finally, the coefficient of CFEER is negative and not statistically significant. This 
negative coefficient may indicate that banks that engage in non depository activities tend to allocate less loan loss provisions; however the insignificance of the coefficient leads us to conclude that there is insufficient evidence to support this assertion. Finally, DCROSS is not statistically significant. This indicates that cross listing is not associated with earnings management.

\section{[Insert Table 4 about Here]}

\subsection{Sensitivity Analysis}

In order to verify the robustness of our results we performed several sensitivity tests with respect to the study period and the estimation of key variables. First, we rerun all equations excluding 2008 data because that year was represented by the wide spread financial crisis. Our results did not change. Hence, we conclude that our findings are robust with respect to the estimation window. We also winsorized one percent of the higher and lower ends of our observations to mitigate the effects of outliers on our inferences and re-estimated our models. Again, there were no significant differences in our results.

Additionally, we tested for the association between LLPs and capital management (measured as Tier II capital). Models (1) and (2) were re-estimated by defining MCAP as the ratio of regulatory capital (Tier II) to the minimum required regulatory capital. Our objective was to examine whether holding LLPs to a maximum of 1.25 per cent of riskweighted assets changes the relation between LLPs and the aforementioned variables. 
Untabulated results show no evidence to indicate that earnings and capital management behavior change significantly in the presence of Tier II capital.

Since June 2000, a special compulsory loan loss provisioning framework - called statistical provisioning or dynamic provisions - has been introduced by Banco de Espana for Spanish banks. This mechanism requires banks to increase their LLPs when loan growth is higher, i.e. when profits tend to be higher. In order to check for possible bias arising from this legislation in the Spanish banking sector we ran the regressions again omitting the Spanish banks from the sample; the results remained qualitatively unchanged. Moreover, we re-estimated all models using only the Spanish banks so as to control whether these banks LLP's behavior shows any peculiarities with respect to the other sample banks. The results suggest that earnings and capital management are similar to the full sample. However, IFRSs do not appear to be of any influence ${ }^{8}$.

Some researchers have suggested that LLPs be dichotomized into its "discretionary" and "non-discretionary" components (see Hasan and Wall 2004; Lobo and Yang 2001). To control for the non-discretionary component of LLPs we introduced the variable $\triangle$ LOAN in the models (estimated as the annual change of the ratio of total loans to total assets of bank i at time t). The influence of this variable on loan loss provisions depends on the quality of incremental loans (Lobo and Yang 2001). Our empirical findings remain unchanged.

\footnotetext{
${ }^{8}$ We thank an anonymous reviewer for making this suggestion.
} 
Since our research sample comprises pooled cross-sectional and time series data the tstatistics could be overstated. In order to control for this source of bias we conducted a panel data analysis and re-estimated all models using the fixed effect method. The results (untabulated) are consistent with the results reported earlier on tables 4 and 5. Finally, we note that there are no significant survivorship biases in our sample since none of our sample banks engaged in mergers or acquisitions or filed for bankruptcy during the period of our analysis.

\section{Conclusions}

The required adoption of International Financial Reporting Standards (IFRS) in Europe stimulated research on the implications and consequences of IFRS on a number of important issues. In this paper we focus on that aspect of this research niche examining the influence of IFRS on earnings management (with emphasis on the use of LLPs as an earnings management tool). There are two opposing views: one view suggesting that IFRS should improve earnings quality and the other that it could reduce quality of reported earnings. The former view is advocated by Barth et al. (2008) who noted that limiting managerial discretion relating to accounting alternatives could eliminate a firm's ability to report accounting numbers that are not reflective of the firm's economic position and performance. The latter view (i.e., IFRS could reduce quality of earnings) is based on the premise that IFRS allows for less latitude by admitting a very limited number of options and prohibiting hidden reserves. The results on whether IFRS does in fact increase reported quality of earnings are mixed. We contribute to the extant literature by focusing on whether IFRS changes earnings management behavior for listed commercial banks using loan loss provisions. We use extensive data comprising EU 
banks covering a ten year period straddling pre and post IFRS regimes. Our findings show that banks manipulate earnings through LLPs but the implementation of IFRS has significantly mitigated earnings management behavior. We also find that, overall, while more risky banks engaged in significant earnings management using LLPs prior to implementation of IFRS, the propensity by these banks to engage in similar behavior has been significantly mitigated in the post IFRS regime. As a subsidiary issue we also examined if capital management behavior had changed after implementation of IFRS. We find that, overall, high risk banks maintain higher levels of LLPs which is intuitively comprehensible. We find no evidence to indicate that, overall, (irrespective of the level of distress of the banks or the type of regime), LLPs are used for capital management. We also find that early adopters do not materially differ to mandatory adopters in terms of LLP behavior.

Our main contribution to the literature is that we show earnings management has been significantly impacted by the change to IFRS, supporting the view that limiting accounting discretion could deter opportunistic behavior by managers. We find that risky banks use LLPs for earnings management but this opportunistic behavior is mitigated in the post-IFRS era. Overall, we conclude that financially stressed banks reporting under IFRS improve their reporting quality, i.e. indicating the superiority of IFRS over local standards for this particular group. We were however unable to check whether differential enforcement, litigation and managerial incentives attributed to our results. Our results are robust to several sensitivity tests including alternative definitions of bank capital, country 
specific effects, regulation on bank capital requirements, and discretionary component of LLPs.

We end by providing suggestions for future research. An avenue for future research could entail research extending our understanding on whether reduced earnings management by riskier banks is anticipated by the market. We also note that the explanatory power of the models could be enhanced by incorporating corporate governance variables in the analysis (e.g., board structure and independence, foreign directorship, CEO tenure and duality) and ownership structure variables. Incorporating these variables and extending this study would be another avenue for future research. Finally, as mentioned in the text, there are two alternative theoretical explanations for the positive coefficient of the EBT and the interactive variable, IFRS*EBT; earnings management versus prudent risk management. Some further research is needed to enlighten further between the two opposing anticipations.

\section{Acknowledgments}

We are grateful to an anonymous reviewer, Pauline Weetman, Mario Levis and Eli Amir for helpful comments on an earlier draft of this paper. 


\section{References}

Ahmed ASC, Takeda C, Thomas S (1999) Bank loan loss provisions: a reexamination of capital management, earnings management and signaling effects. Journal of Accounting and Economics 29:1-25.

Anandarajan A, Hasan I, Lozano-Vivas A (2003) The role of loan loss provisions in earnings management, capital management and signaling: The Spanish experience. Advances in International Accounting 16:45-65.

Anandarajan A, Hasan I, McCarthy C (2007) Use of loan loss provisions for capital, earnings management and signaling by Australian banks. Accounting and Finance 47:357-379.

Anderson R, Fraser D (2000) Corporate control, bank risk taking and the health of the banking industry. Journal of Banking and Finance 24:1383-1398.

Armstrong CS, Barth M, Jagolinzer AD, and Riedl EJ (2010) Market reaction to the adoption of IFRS in Europe. The Accounting Review 85:31-61.

Ashbaugh H, Pincus M (2001) Domestic accounting standards, international accounting standards and the predictability of earnings. Journal of Accounting Research 39: 417-434.

Australian Prudential Regulation Authority (2005) Adoption of International Financial Reporting Standards: Prudential approach 2. Tier 1 capital and securitization. APRA working paper, August 2005.

Ball R, Robin A, Wu JS (2003) Incentives versus standards: Properties of accounting income in four East Asian countries. Journal of Accounting and Economics $36: 235-270$. 
Bank for International Settlements (2005) International convergence on capital measurement and capital standards. Basel, Switzerland.

Barro RJ (1990) The stock market and investment. The Review of Financial Studies 3: $115-131$.

Barth ME, Landsman WR, Lang MH (2008), International accounting standards and accounting quality. Journal of Accounting Research 46:467-498.

Basel Committee on Banking Supervision (2005a) The Application of Basel II to Trading Activities and the Treatment of Double Default Effects. Bank for International Settlements, July 2005.

Basel Committee on Banking Supervision (2005b) International Convergence of Capital Measurement and Capital Standards. Bank for International Settlements. November 2005.

Basel Committee on Banking Supervision (2005c) Amendment to the Capital Accord to incorporate market risks. Bank for International Settlements, November 2005.

Beatty A, Chamberlain S, Magliolo J (1995) Managing financial reports of commercial banks: the influence of taxes, regulatory capital and earnings. Journal of Accounting Research 33:231-262.

Beaver W, Engel E (1996) Discretionary behavior with respect to allowances for loan losses and the behavior of stock prices. Journal of Accounting and Economics 22:177-206.

Bhat V (1996) Banks and income smoothing: an empirical analysis. Applied Financial Economics 6:505-510. 
Blanchard O, Rhee C, Summers L (1993) The stock market, profit and investment. The Quarterly Journal of Economics. 108:115-136

Breeden R (1994) Foreign companies and US markets in a time of economic transformation. Fordham International Law Journal 17:77-96.

Boyd J, Graham S, Hewitt R (1993) Bank holding company mergers with non-bank financial firms: Effects on the risk of failure. Journal of Banking and Finance 17:43-63.

Burgstahler D, Hail L, Leuz C (2006) The importance of reporting incentives:

Earnings management in European private and public firms. The Accounting Review 81:983-1016.

Busch A (2009) Banking regulation and globalization. Oxford University Press, USA.

Cairns D (1999) Degrees of compliance. Accountancy International 68-69.

Chang SJ, Chen S (1991) Information effects of earnings and dividend announcements on common stock returns: Are they interactive?. Journal of Economics and Business 43:179-192.

Collins J, Shackelford D, Wahlen J (1995) Bank differences in the coordination of regulatory capital, earnings and taxes. Journal of Accounting Research, 33:263292.

EFRAG (2009) European Financial Reporting Advisory Group. http://www.efrag.org/homepage.asp.

Epstein BJ, Jermakowicz EK (2007) IFRS 2007: Interpretation and application of International Financial Reporting Standards. Wiley publications. 
Ewert R, Wagenhofer A (2005) Economic effects of tightening accounting standards to restrict earnings management. The Accounting Review 43:1101-1124.

Financial Stability Board (2009) Report of the Financial Stability Board to G20 leaders, secretariat based in Basel, Switzerland.

Greenawalt MB, Sinkey JF (1988) Bank loan loss provisions and the income smoothing hypothesis: An empirical analysis, 1976-1984. Journal of Financial Services Research 1:301-318.

Grier W (2005) Valuing a Bank Under IAS/IFRS and Basel II. Self-study Solutions.

Hasan I, Wall L (2004) Determinants of the Loan Loss Allowance: Some Cross-Country Comparisons. The Financial Review 39:129-152.

Healy PM, Wahlen JM (1999) A review of the earnings management literature and its implications for standard setting. Accounting Horizons 13:365-384.

Iannotta G (2006) Testing for opaqueness in the European banking industry: evidence from bond credit ratings. Journal of Financial Services Research 30:287-309.

IASB (2008) International Financial Reporting Standards. International Accounting Standards Board, London.

International Accounting Standards Committee (2003) IAS 39 Financial Instruments:

Recognition and Measurement. Revised version, December 2003, London, UK, IASC.

Kim M, Kross W (1998) The impact of the 1989 change in bank capital standards on loan loss provisions and loan write-offs. Journal of Accounting and Economics 25:69100.

Kothari SP (2001) Capital markets research in accounting. Journal of Accounting and 
Economics 31:105-231.

Lang M, Raedy J, Wilson W (2006) Earnings management and cross listing: are reconciled earnings comparable to US earnings?. Journal of Accounting and Economics 42:255-283.

Laurin A, Majnoni G (2003) Bank loan Classification and Provisioning Practices in Selected Developed and Emerging Countries. World Bank Working paper 1, The World Bank.

Liu C, Ryan S (1995) The effect of bank loan portfolio composition on the market reaction to and anticipation of loan loss provisions. Journal of Accounting Research 33:77-94.

Liu C, Ryan S, Wahlen J (1997) Differential valuation implications of loan loss provisions across bank and fiscal agents. The Accounting Review 72:133-146.

Lobo GJ, Yang DH (2001) Bank managers’ heterogeneous decisions on discretionary loan loss provisions. Review of Quantitative Finance and Accounting 16:223-250.

Ma C.K (1988) Loan loss reserve and income smoothing: the experience in the US banking industry. Journal of Business Finance and Accounting 15:487-497. Moyer SE (1990) Capital adequacy ratio regulations and accounting choices in commercial banks. Journal of Accounting and Economics 13:123-154.

Penman S (2001) Financial statement analysis and security valuation. McGraw Hill, International edition.

Penman S, Sougiannis T (1997) The dividend displacement property and the substitution of anticipated earnings for dividends in equity valuation. The Accounting Review 72:1-21. 
Pérez D, Salas-Fumás V, Saurina J (2008) Earnings and capital management in alternative loan loss provision regulatory regimes. European Accounting Review $17: 423-445$.

PricewaterhouseCoopers' Accounting Consulting Services Team (2009) IFRS Manual of Accounting 2009. PricewaterhouseCoopers.

Scheiner J H (1981) Income smoothing: An analysis in the banking industry. Journal of Bank Research 12:119-123.

Scholes M, Wilson G.P, Wolfson M (1990) Tax planning, regulatory capital planning and financial reporting strategy for commercial banks. Review of Financial Studies 3: 625-650.

Shrieves R, Dahl D (2003) Discretionary accounting and the behaviour of Japanese banks under financial duress. Journal of Banking and Finance 27:1219-1243.

Street DL, Gray SJ (2002) Factors influencing the extent of corporate compliance with International Accounting Standards: summary of a research monograph. Journal of International Accounting, Auditing \& Taxation 11:51-76.

Tarullo DK (2008) Banking on Basel: The Future of International Financial Regulation. Peterson Institute for International Economics.

Van Tendeloo B, Vanstraelen A (2005) Earnings management under German GAAP versus IFRS. European Accounting Review 4(1):155-180.

Wall LD, Koch TW (2000) Bank loan loss accounting: A review of theoretical and empirical evidence. Federal Reserve Bank of Atlanta Economic Review, second quarter, 1-17. 
World Bank (2003) Bank loan classification and provisioning practices in selected developed and emerging economies. World Bank working paper No. 26056, March 2003, The World Bank, Washington D.C.

Yasuda Y, Okuda S, Konishi M (2004) The relationship between bank risk and earnings

management: Evidence from Japan. Review of Quantitative Finance and Accounting 22:233-248. 
Table 1: Sample selection procedure

European Banks included in the Thomson database

Less: non-commercial banks

Remaining financial firms

192

Less: Banks with incomplete accounting data

(101)

Bank included in the final sample 
Table 2: Descriptive statistics of sample variables

The sample includes 91 listed banking firms (35 voluntary-IFRS adopters and 56 mandatory-IFRS adopters) from 18 European countries over the period 1999-2008. LLPR is the ratio of loan loss provisions to total loans, MCAP is the ratio of actual regulatory capital (Tier 1 capital) before loan loss reserves to the minimum required regulatory capital, EBT is the ration of earnings before taxes and LLPs to total assets, $\triangle E B T$ is the annual change of earnings before taxes and LLPs, LnTA is the natural logarithm of total assets capturing the effect of bank size, CFEER is the ratio of commission and fee income to total assets, $\Delta$ GDP is the change in gross domestic product, a proxy for the change in economic growth

Panel A: Mandatory IFRS adopters

\begin{tabular}{|c|c|c|c|c|c|c|c|c|c|c|c|c|c|c|c|}
\hline \multirow{2}{*}{ Variables } & \multicolumn{5}{|c|}{ Full Sample } & \multicolumn{5}{|c|}{ Pre-IFRS } & \multicolumn{5}{|c|}{ Post-IFRS } \\
\hline & Mean & Median & St.D & Min & Max & Mean & Median & St.D & Min & Max & Mean & Median & St.D & Min & Max \\
\hline LLPR & 0.0061 & 0.0049 & 0.0067 & 0.0002 & 0.087 & 0.0057 & 0.0044 & 0.0065 & 0.0001 & 0.063 & 0.0063 & 0.0052 & 0.007 & 0.003 & 0.088 \\
\hline MCAP & 1.510 & 0.716 & 4.896 & 0.004 & 109.5 & 1.789 & 0.706 & 5.962 & 0.004 & 109.6 & 1.087 & 0.739 & 2.482 & 0.015 & 25.51 \\
\hline EBT & 0.016 & 0.014 & 0.011 & -0.031 & 0.118 & 0.015 & 0.013 & 0.011 & -0.030 & 0.119 & 0.017 & 0.016 & 0.010 & -0.018 & 0.057 \\
\hline$\triangle \mathrm{EBT}$ & 0.0008 & 0.0013 & 0.0103 & -0.126 & 0.071 & 0.002 & 0.001 & 0.009 & -0.065 & 0.071 & 0.005 & 0.001 & 0.008 & -0.126 & 0.058 \\
\hline LnTA & 100.96 & 97.40 & 19.32 & 46.88 & 147.6 & 98.69 & 95.55 & 18.90 & 46.88 & 139.3 & 104.3 & 100.7 & 19.47 & 54.78 & 147.6 \\
\hline CFEER & 0.014 & 0.012 & 0.009 & 0.0009 & 0.144 & 0.013 & 0.012 & 0.009 & 0.001 & 0.113 & 0.014 & 0.012 & 0.008 & 0.001 & 0.063 \\
\hline$\Delta$ GDP & 0.028 & 0.023 & 0.049 & -0.144 & 0.335 & 0.027 & 0.029 & 0.048 & -0.110 & 0.334 & 0.028 & 0.021 & 0.051 & -0.143 & 0.223 \\
\hline
\end{tabular}

Panel B: Voluntary IFRS adopters

\begin{tabular}{|c|c|c|c|c|c|c|c|c|c|c|}
\hline \multirow{2}{*}{ Variables } & \multicolumn{5}{|c|}{ Pre-IFRS } & \multicolumn{5}{|c|}{ Post-IFRS } \\
\hline & Mean & Median & St.D & Min & Max & Mean & Median & St.D & Min & Max \\
\hline LLPR & 0.0058 & 0.0047 & 0.0060 & 0.0002 & 0.069 & 0.0071 & 0.0057 & 0.009 & 0.006 & 0.092 \\
\hline MCAP & 1.810 & 0.667 & 4.712 & 0.007 & 114.66 & 1.415 & 0.973 & 3.781 & 0.014 & 55.72 \\
\hline EBT & 0.014 & 0.011 & 0.012 & -0.001 & 0.103 & 0.021 & 0.017 & 0.008 & -0.014 & 0.147 \\
\hline$\triangle E B T$ & 0.001 & 0.0009 & 0.008 & -0.087 & 0.093 & 0.0007 & 0.0003 & 0.006 & -0.131 & 0.060 \\
\hline LnTA & 84.64 & 89.45 & 17.76 & 47.65 & 121.45 & 90.22 & 91.36 & 18.01 & 56.33 & 132.1 \\
\hline CFEER & 0.004 & 0.006 & 0.008 & 0.0009 & 0.10 & 0.012 & 0.007 & 0.005 & 0.0004 & 0.011 \\
\hline$\Delta$ GDP & 0.027 & 0.029 & 0.048 & -0.110 & 0.334 & 0.028 & 0.021 & 0.051 & -0.143 & 0.223 \\
\hline
\end{tabular}


Table 3: Pearson correlation coefficients of sample variables

The sample includes 91 listed banking firms from 18 European countries over the period 1999-2008. LLPR is the ratio of loan loss provisions to total loans, MCAP is the ratio of actual regulatory capital (Tier 1 capital) before loan loss reserves to the minimum required regulatory capital, EBT is the ration of earnings before taxes and LLPs to total assets, LnTA is the natural logarithm of total assets capturing the effect of bank size, CFEER is the ratio of commission and fee income to total assets, $\triangle$ GDP is the change in gross domestic product, a proxy for the change in economic growth.

\begin{tabular}{c|ccccc}
\hline Variables & LLPR & MCAP & EBT & LnTA & CFEER \\
\hline MCAP & -0.037 & & & & \\
& $(0.266)$ & & & & \\
EBT & $0.194^{* * *}$ & 0.013 & & & \\
& $(0.000)$ & $(0.695)$ & & & \\
LnTA & $-0.066^{* * *}$ & -0.025 & $-0.211^{* * *}$ & & \\
& $(0.048)$ & $(0.459)$ & $(0.000)$ & & \\
CFEER & $0.094^{* * *}$ & $0.133^{* * *}$ & $0.449^{* * *}$ & $-0.183^{* * *}$ & \\
& $(0.004)$ & $(0.000)$ & $(0.000)$ & $(0.000)$ & \\
$\Delta$ GDP & -0.013 & -0.014 & $0.121^{* * *}$ & $-0.140^{* * *}$ & $0.141^{* * *}$ \\
& $(0.715)$ & $(0.681)$ & $(0.001)$ & $(0.000)$ & $(0.000)$ \\
\hline
\end{tabular}

$\mathrm{p}$-values in the parentheses, ${ }^{* * *}$ denotes significance at a $=1 \%$ significance level. 
Table 4: Regression analysis of IFRS voluntary adopters

LLPR is the ratio of loan loss provisions to total loans, MCAP is the ratio of actual regulatory capital (Tier 1 capital) before loan loss reserves to the minimum required regulatory capital, EBT is the ration of earnings before taxes and LLPs to total assets, IFRS is a binary variable taking the value of (1) for the early adopters and (0) otherwise, $\mathrm{Dz}$ is a dummy variable which takes the value of (1) for observations lying below the median of sample's Z-score developed by Boyd et. al (1993) indicating the probability of bankruptcy, LnTA is the natural logarithm of total assets capturing the effect of bank size, CFEER is the ratio of commission and fee income to total assets, $\triangle$ GDP is the change in gross domestic product, a proxy for the change in economic growth, DCROSS is a dummy receiving (1) if a bank is cross-listed and (0) otherwise

\begin{tabular}{|c|c|c|c|c|}
\hline Variables & Model 1a & Model 1b & Model 1c & Model 1d \\
\hline Intercept & $\begin{array}{c}0.0071 * * * \\
(4.33)\end{array}$ & $\begin{array}{c}0.0074 * * * \\
(4.47)\end{array}$ & $\begin{array}{c}0.0073 * * * \\
(4.40)\end{array}$ & $\begin{array}{c}0.0071^{* * *} \\
\quad(4.24)\end{array}$ \\
\hline MCAP & $\begin{array}{c}-0.00015 \\
(-0.42)\end{array}$ & $\begin{array}{c}-0.00050 \\
(-1.12)\end{array}$ & $\begin{array}{c}-0.00055 \\
(-0.83)\end{array}$ & $\begin{array}{c}-0.00044 \\
(-0.59)\end{array}$ \\
\hline EBT & $\begin{array}{c}0.051^{* *} \\
(2.21)\end{array}$ & $\begin{array}{c}0.039 * * \\
(1.86)\end{array}$ & $\begin{array}{c}0.044^{* *} \\
(1.77)\end{array}$ & $\begin{array}{c}0.025 * * \\
(2.00)\end{array}$ \\
\hline IFRS & $\begin{array}{c}-0.0068 \\
(-0.10)\end{array}$ & & $\begin{array}{c}-0.0001 \\
(-0.02)\end{array}$ & $\begin{array}{c}-0.0008 \\
(-0.12)\end{array}$ \\
\hline IFRS*MCAP & $\begin{array}{c}-0.00003 \\
(-0.39)\end{array}$ & & $\begin{array}{c}-0.00001 \\
(-0.09)\end{array}$ & $\begin{array}{c}-0.00001 \\
(-0.05)\end{array}$ \\
\hline IFRS*EBT & $\begin{array}{l}0.011 \\
(0.32)\end{array}$ & & $\begin{array}{c}0.0096 \\
(0.30)\end{array}$ & $\begin{array}{c}0.037 * * \\
(2.30)\end{array}$ \\
\hline $\mathbf{D z}$ & $\begin{array}{c}-0.0023^{* * *} \\
(-6.04)\end{array}$ & $\begin{array}{c}-0.0028 * * * \\
(-4.13)\end{array}$ & $\begin{array}{c}-0.0028 * * * \\
(-4.13)\end{array}$ & $\begin{array}{c}-0.0029 * * * \\
(-4.27)\end{array}$ \\
\hline Dz*MCAP & & $\begin{array}{c}-0.00051 \\
(-0.85)\end{array}$ & $\begin{array}{c}-0.00054 \\
(-0.17)\end{array}$ & $\begin{array}{c}-0.00042 \\
(-0.49)\end{array}$ \\
\hline Dz*EBT & & $\begin{array}{l}0.021 \\
(0.65)\end{array}$ & $\begin{array}{l}0.023 \\
(0.68)\end{array}$ & $\begin{array}{c}0.076^{* * *} \\
(2.80)\end{array}$ \\
\hline IFRS*Dz*MCAP & & & & $\begin{array}{c}0.00001 \\
(0.08)\end{array}$ \\
\hline IFRS*Dz*EBT & & & & $\begin{array}{c}-0.103 * * * \\
(-2.81)\end{array}$ \\
\hline LnTA & $\begin{array}{c}-0.0003 * * \\
(-2.34)\end{array}$ & $\begin{array}{c}-0.00032^{* *} \\
(-2.58)\end{array}$ & $\begin{array}{c}-0.0003 * * \\
(-2.33)\end{array}$ & $\begin{array}{c}-0.00028 * * \\
(-2.20)\end{array}$ \\
\hline CFEER & $\begin{array}{l}-0.0082 \\
(-0.32)\end{array}$ & $\begin{array}{l}-0.014 \\
(-0.61)\end{array}$ & $\begin{array}{l}-0.013 \\
(-0.56)\end{array}$ & $\begin{array}{l}-0.018 \\
(-0.78)\end{array}$ \\
\hline$\Delta G D P$ & $\begin{array}{c}-0.0085^{* *} \\
(-2.10)\end{array}$ & $\begin{array}{c}-0.0088 * * \\
(-2.20)\end{array}$ & $\begin{array}{c}-0.0087 * * \\
(-2.15)\end{array}$ & $\begin{array}{c}-0.0091 * * \\
(-2.25)\end{array}$ \\
\hline DCROSS & $\begin{array}{c}0.00032 \\
(0.66)\end{array}$ & $\begin{array}{c}0.00033 \\
(0.68)\end{array}$ & $\begin{array}{c}0.00034 \\
(0.69)\end{array}$ & $\begin{array}{c}0.0027 \\
(0.57)\end{array}$ \\
\hline $\begin{array}{c}\mathbf{R}^{2} \text {-adjusted } \\
\text { F-statistic } \\
\text { Observations }\end{array}$ & $\begin{array}{c}17.2 \% \\
7.79 * * * \\
910\end{array}$ & $\begin{array}{c}17.3 \% \\
8.16^{* * * *} \\
910\end{array}$ & $\begin{array}{c}17.1 \% \\
7.24 * * * \\
910\end{array}$ & $\begin{array}{c}17.7 \% \\
7.07 * * * \\
910\end{array}$ \\
\hline
\end{tabular}


T-statistics are in the parentheses. ***, ** denote significance at the $1 \%$ and $5 \%$ significance level respectively (two-tailed test). All model specifications include year dummies and country dummies for capturing unobserved effects. 
Table 5: Regression analysis of IFRS mandatory adopters

LLPR is the ratio of loan loss provisions to total loans, MCAP is the ratio of actual regulatory capital (Tier 1 capital) before loan loss reserves to the minimum required regulatory capital, EBT is the ration of earnings before taxes and LLPs to total assets, IFRS is a binary variable taking the value of (1) for the post-IFRS period and (0) otherwise, Dz is a dummy variable which takes the value of (1) for observations lying below the median of sample's Z-score developed by Boyd et. al (1993) indicating the probability of bankruptcy, LnTA is the natural logarithm of total assets capturing the effect of bank size, CFEER is the ratio of commission and fee income to total assets, $\triangle \mathrm{GDP}$ is the change in gross domestic product, a proxy for the change in economic growth, DCROSS is a dummy receiving (1) if a bank is cross-listed and (0) otherwise

\begin{tabular}{c|cccc}
\hline Variables & Model 1a & Model 1b & Model 1c & Model 1d \\
\hline Intercept & $0.0070^{* * *}$ & $0.0074^{* * *}$ & $0.0072^{* * *}$ & $0.0071^{* * *}$ \\
& $(4.24)$ & $(4.47)$ & $(4.30)$ & $(4.26)$ \\
MCAP & -0.00047 & -0.00051 & -0.00022 & -0.00002 \\
& $(-0.13)$ & $(-1.12)$ & $(-0.32)$ & $(-0.03)$ \\
EBT & $0.048^{* *}$ & $0.040^{* *}$ & $0.041^{* *}$ & $0.030^{* *}$ \\
& $(2.18)$ & $(1.86)$ & $(1.68)$ & $(2.23)$ \\
IFRS & -0.0039 & & -0.0043 & -0.0035 \\
& $(-0.63)$ & & $(-0.86)$ & $(-0.55)$ \\
IFRS*MCAP & -0.00008 & & -0.0006 & -0.00009 \\
& $(-1.14)$ & & $(-0.80)$ & $(-0.99)$ \\
IFRS*EBT & 0.0025 & & 0.0027 & $0.029^{* *}$ \\
& $(0.08)$ & & $(1.08)$ & $(1.81)$ \\
Dz & $-0.0023^{* * *}$ & $-0.0028^{* * *}$ & $-0.0029^{* * *}$ & $-0.0027 * *$ \\
& $(-5.91)$ & $(-4.13)$ & $(-4.03)$ & $(-4.03)$ \\
Dz*MCAP & & -0.00051 & -0.00026 & -0.00001 \\
& & $(-0.85)$ & $(-0.37)$ & $(-0.01)$ \\
Dz*EBT & & 0.021 & $0.023^{* *}$ & $0.051^{* *}$ \\
& & $(0.65)$ & $(1.69)$ & $(1.67)$ \\
IFRS*Dz*MCAP & & & & 0.00007 \\
& & & & $(0.46)$ \\
IFRS*Dz*BT & & & & $-0.060^{* *}$ \\
& & & & $(-1.62)$ \\
LnTA & $-0.00027^{* *}$ & $-0.00031^{* *}$ & $-0.00029^{* *}$ & $-0.00028^{* *}$ \\
& $(-2.29)$ & $(-2.58)$ & $(-2.31)$ & $(-2.30)$ \\
CFEER & -0.0092 & -0.014 & -0.014 & -0.017 \\
& $(-0.41)$ & $(-0.63)$ & $(-0.60)$ & $(-0.74)$ \\
$\Delta$ GDDP & $-0.0084^{* *}$ & $-0.0089^{*}$ & $-0.0086^{* *}$ & $-0.0088^{* *}$ \\
& $(-2.08)$ & $(-2.20)$ & $(-2.10)$ & $(-2.16)$ \\
DCROSS & 0.0032 & 0.0033 & 0.0032 & 0.0026 \\
& $(0.66)$ & $(0.69)$ & $(0.67)$ & $(0.55)$ \\
\hline & & & &
\end{tabular}




\begin{tabular}{c|cccc}
\hline $\mathbf{R}^{2}$-adjusted & $17.4 \%$ & $17.3 \%$ & $17.2 \%$ & $17.3 \%$ \\
F-statistic & $7.89 * * *$ & $8.16^{* * *}$ & $7.32^{* * *}$ & $6.91^{* * *}$ \\
Observations & 910 & 910 & 910 & 910 \\
\hline
\end{tabular}

T-statistics are in the parentheses. ${ }^{* * *},{ }^{* *}$ denote significance at the $1 \%$ and $5 \%$ significance level respectively (two-tailed test). All model specifications include year dummies and country dummies for capturing unobserved effects. 